\title{
Cyclic nucleotide-regulated channels (version 2019.4) in the IUPHAR/BPS Guide to Pharmacology Database
}

\author{
Elvir Becirovic ${ }^{1}$, Martin Biel ${ }^{1}$, Verena Hammelmann ${ }^{1}$, Franz Hofmann ${ }^{2}$ and U. Benjamin Kaupp ${ }^{3}$ \\ 1. Ludwig-Maximilians-Universität, Germany \\ 2. Technische Universität München, Germany \\ 3. Forschungszentrum Jülich, Germany
}

\begin{abstract}
Cyclic nucleotide-gated (CNG) channels are responsible for signalling in the primary sensory cells of the vertebrate visual and olfactory systems.

CNG channels are voltage-independent cation channels formed as tetramers. Each subunit has 6TM, with the pore-forming domain between TM5 and TM6. CNG channels were first found in rod photoreceptors [69, 98], where light signals through rhodopsin and transducin to stimulate phosphodiesterase and reduce intracellular cyclic GMP level. This results in a closure of CNG channels and a reduced 'dark current'. Similar channels were found in the cilia of olfactory neurons [153] and the pineal gland [60]. The cyclic nucleotides bind to a domain in the $\mathrm{C}$ terminus of the subunit protein: other channels directly binding cyclic nucleotides include HCN, eag and certain plant potassium channels.
\end{abstract}

\section{Hyperpolarisation-activated, cyclic nucleotide-gated (HCN)}

The hyperpolarisation-activated, cyclic nucleotide-gated (HCN) channels are cation channels that are activated by hyperpolarisation at voltages negative to $\sim-50 \mathrm{mV}$. The cyclic nucleotides cyclic AMP and cyclic GMP directly activate the channels and shift the activation curves of $\mathrm{HCN}$ channels to more positive voltages, thereby enhancing channel activity. $\mathrm{HCN}$ channels underlie pacemaker currents found in many excitable cells including cardiac cells and neurons $[56,164]$. In native cells, these currents have a variety of names, such $a s l_{h}, l_{q}$ and $l_{f}$. The four known HCN channels have six transmembrane domains and form tetramers. It is believed that the channels can form heteromers with each other, as has been shown for HCN1 and HCN4 [2]. High resolution structural studies of $C N G$ and $\mathrm{HCN}$ channels has provided insight into the the gating processes of these channels [117, 121]. A standardised nomenclature for CNG and HCN channels has been proposed by the NC-IUPHAR subcommittee on voltage-gated ion channels [88].

\section{Contents}

This is a citation summary for Cyclic nucleotide-regulated channels in the Guide to Pharmacology database (GtoPdb). It exists purely as an adjunct to the database to facilitate the recognition of citations to and from the database by citation analyzers. Readers will almost certainly want to visit the relevant sections of the database which are given here under database links.

GtoPdb is an expert-driven guide to pharmacological targets and the substances that act on them. GtoPdb is a 
reference work which is most usefully represented as an on-line database. As in any publication this work should be appropriately cited, and the papers it cites should also be recognized. This document provides a citation for the relevant parts of the database, and also provides a reference list for the research cited by those parts.

Please note that the database version for the citations given in GtoPdb are to the most recent preceding version in which the family or its subfamilies and targets were substantially changed. The links below are to the current version. If you need to consult the cited version, rather than the most recent version, please contact the GtoPdb curators.

\section{Database links}

Cyclic nucleotide-regulated channels

http://www.guidetopharmacology.org/GRAC/FamilyDisplayForward?familyld=71

Introduction to Cyclic nucleotide-regulated channels

http://www.guidetopharmacology.org/GRAC/FamilyIntroductionForward?familyld=71

Channels and Subunits

CNGA1

http://www.guidetopharmacology.org/GRAC/ObjectDisplayForward?objectld=394

CNGA2

http://www.guidetopharmacology.org/GRAC/ObjectDisplayForward?objectld=395

CNGA3

http://www.guidetopharmacology.org/GRAC/ObjectDisplayForward?objectld=396

CNGA4

http://www.guidetopharmacology.org/GRAC/ObjectDisplayForward?objectld=397

CNGB1

http://www.guidetopharmacology.org/GRAC/ObjectDisplayForward?objectld=398

CNGB3

http://www.guidetopharmacology.org/GRAC/ObjectDisplayForward?objectld=399

HCN1

http://www.guidetopharmacology.org/GRAC/ObjectDisplayForward?objectld=400

$\mathrm{HCN} 2$

http://www.guidetopharmacology.org/GRAC/ObjectDisplayForward?objectld=401

HCN3

http://www.guidetopharmacology.org/GRAC/ObjectDisplayForward?objectld=402

$\mathrm{HCN} 4$

http://www.guidetopharmacology.org/GRAC/ObjectDisplayForward?objectld=403

\section{References}

1. Ahuja Y, Kohl S and Traboulsi El. (2008) CNGA3 mutations in two United Arab Emirates families with achromatopsia. Mol. Vis. 14: 1293-7 [PMID:18636117]

2. Altomare C, Terragni B, Brioschi C, Milanesi R, Pagliuca C, Viscomi C, Moroni A, Baruscotti M and DiFrancesco D. (2003) Heteromeric HCN1-HCN4 channels: a comparison with native pacemaker channels from the rabbit sinoatrial node. J. Physiol. (Lond.) 549: 347-59 [PMID:12702747]

3. Ardell MD, Aragon I, Oliveira L, Porche GE, Burke E and Pittler SJ. (1996) The beta subunit of human rod photoreceptor CGMP-gated cation channel is generated from a complex transcription unit. FEBS Lett. 389: 213-8 [PMID:8766832]

4. Ardell MD, Bedsole DL, Schoborg RV and Pittler SJ. (2000) Genomic organization of the human rod photoreceptor cGMP-gated cation channel beta-subunit gene. Gene 245: 311-8 [PMID:10717482]

5. Ardell MD, Makhija AK, Oliveira L, Miniou P, Viegas-Péquignot E and Pittler SJ. (1995) cDNA, gene 
structure, and chromosomal localization of human GAR1 (CNCG3L), a homolog of the third subunit of bovine photoreceptor cGMP-gated channel. Genomics 28: 32-8 [PMID:7590744]

6. Azam M, Collin RW, Shah ST, Shah AA, Khan MI, Hussain A, Sadeque A, Strom TM, Thiadens AA and Roosing $S$ et al.. (2010) Novel CNGA3 and CNGB3 mutations in two Pakistani families with achromatopsia. Mol. Vis. 16: 774-81 [PMID:20454696]

7. Bankston JR, Camp SS, DiMaio F, Lewis AS, Chetkovich DM and Zagotta WN. (2012) Structure and stoichiometry of an accessory subunit TRIP8b interaction with hyperpolarization-activated cyclic nucleotide-gated channels. Proc. Natl. Acad. Sci. U.S.A. 109: 7899-904 [PMID:22550182]

8. Barbuti A, Scavone A, Mazzocchi N, Terragni B, Baruscotti M and Difrancesco D. (2012) A caveolinbinding domain in the HCN4 channels mediates functional interaction with caveolin proteins. J. Mol. Cell. Cardiol. 53: 187-95 [PMID:22659290]

9. Bareil C, Hamel CP, Delague V, Arnaud B, Demaille J and Claustres M. (2001) Segregation of a mutation in CNGB1 encoding the beta-subunit of the rod cGMP-gated channel in a family with autosomal recessive retinitis pigmentosa. Hum. Genet. 108: 328-34 [PMID:11379879]

10. Barnstable CJ and Wei J-Y. (1995) Isolation and characterization of the alpha-subunit of the rat rod photoreceptor cGMP-gated cation channel. J. Mol. Neurosci. 6: 289-302 [PMID:8860239]

11. Baruscotti M, Bucchi A and Difrancesco D. (2005) Physiology and pharmacology of the cardiac pacemaker ("funny") current. Pharmacol. Ther. 107: 59-79 [PMID:15963351]

12. Baruscotti M, Bucchi A, Viscomi C, Mandelli G, Consalez G, Gnecchi-Rusconi T, Montano N, Casali KR, Micheloni S and Barbuti A et al.. (2011) Deep bradycardia and heart block caused by inducible cardiacspecific knockout of the pacemaker channel gene Hcn4. Proc. Natl. Acad. Sci. U.S.A. 108: 1705-10 [PMID:21220308]

13. Bauer PJ and Drechsler M. (1992) Association of cyclic GMP-gated channels and $\mathrm{Na}(+)-\mathrm{Ca}(2+)-\mathrm{K}+$ exchangers in bovine retinal rod outer segment plasma membranes. J. Physiol. (Lond.) 451: 109-31 [PMID:1328615]

14. Becirovic E, Nakova K, Hammelmann V, Hennel R, Biel M and Michalakis S. (2010) The retinitis pigmentosa mutation c.3444+1G>A in CNGB1 results in skipping of exon 32. PLOS ONE 5: e8969 [PMID:20126465]

15. Bender RA, Soleymani SV, Brewster AL, Nguyen ST, Beck H, Mathern GW and Baram TZ. (2003) Enhanced expression of a specific hyperpolarization-activated cyclic nucleotide-gated cation channel $(\mathrm{HCN})$ in surviving dentate gyrus granule cells of human and experimental epileptic hippocampus. $J$. Neurosci. 23: 6826-36 [PMID:12890777]

16. Berghard A, Buck LB and Liman ER. (1996) Evidence for distinct signaling mechanisms in two mammalian olfactory sense organs. Proc. Natl. Acad. Sci. U.S.A. 93: 2365-9 [PMID:8637879]

17. Biel M, Seeliger M, Pfeifer A, Kohler K, Gerstner A, Ludwig A, Jaissle G, Fauser S, Zrenner E and Hofmann F. (1999) Selective loss of cone function in mice lacking the cyclic nucleotide-gated channel CNG3. Proc. Natl. Acad. Sci. U.S.A. 96: 7553-7 [PMID:10377453]

18. Biel M, Zong X, Distler M, Bosse E, Klugbauer N, Murakami M, Flockerzi V and Hofmann F. (1994) Another member of the cyclic nucleotide-gated channel family, expressed in testis, kidney, and heart. Proc. Natl. Acad. Sci. U.S.A. 91: 3505-9 [PMID:8170936]

19. Bonin RP, Zurek AA, Yu J, Bayliss DA and Orser BA. (2013) Hyperpolarization-activated current (In) is reduced in hippocampal neurons from Gabra5-/- mice. PLoS ONE 8: e58679 [PMID:23516534]

20. Borlak $\mathrm{J}$ and Thum T. (2003) Hallmarks of ion channel gene expression in end-stage heart failureFASEB J. 17: 1592-608 [PMID:12958166]

21. BoSmith RE, Briggs I and Sturgess NC. (1993) Inhibitory actions of ZENECA ZD7288 on whole-cell hyperpolarization activated inward current (If) in guinea-pig dissociated sinoatrial node cells. Br. J. Pharmacol. 110: 343-9 [PMID:7693281]

22. Bradley J, Bönigk W, Yau KW and Frings S. (2004) Calmodulin permanently associates with rat olfactory CNG channels under native conditions. Nat. Neurosci. 7: 705-10 [PMID:15195096]

23. Bradley J, Li J, Davidson N, Lester HA and Zinn K. (1994) Heteromeric olfactory cyclic nucleotide-gated 
channels: a subunit that confers increased sensitivity to cAMP. Proc. Natl. Acad. Sci. U.S.A. 91: 8890-4 [PMID:7522325]

24. Bradley J, Reisert J and Frings S. (2005) Regulation of cyclic nucleotide-gated channels.Curr. Opin. Neurobiol. 15: 343-9 [PMID:15922582]

25. Bradley J, Reuter D and Frings S. (2001) Facilitation of calmodulin-mediated odor adaptation by cAMPgated channel subunits. Science 294: 2176-8 [PMID:11739960]

26. Bradley J, Zhang Y, Bakin R, Lester HA, Ronnett GV and Zinn K. (1997) Functional expression of the heteromeric "olfactory" cyclic nucleotide-gated channel in the hippocampus: a potential effector of synaptic plasticity in brain neurons. J. Neurosci. 17: 1993-2005 [PMID:9045728]

27. Brady JD, Rich ED, Martens JR, Karpen JW, Varnum MD and Brown RL. (2006) Interplay between PIP3 and calmodulin regulation of olfactory cyclic nucleotide-gated channels. Proc. Natl. Acad. Sci. U.S.A. 103: 15635-40 [PMID:17032767]

28. Brandt MC, Endres-Becker J, Zagidullin N, Motloch LJ, Er F, Rottlaender D, Michels G, Herzig S and Hoppe UC. (2009) Effects of KCNE2 on HCN isoforms: distinct modulation of membrane expression and single channel properties. Am. J. Physiol. Heart Circ. Physiol. 297: H355-63 [PMID:19429827]

29. Brown RL, Haley TL, West KA and Crabb JW. (1999) Pseudechetoxin: a peptide blocker of cyclic nucleotide-gated ion channels. Proc. Natl. Acad. Sci. U.S.A. 96: 754-9 [PMID:9892706]

30. Brown RL, Lynch LL, Haley TL and Arsanjani R. (2003) Pseudechetoxin binds to the pore turret of cyclic nucleotide-gated ion channels. J. Gen. Physiol. 122: 749-60 [PMID:14638933]

31. Brunet LJ, Gold GH and Ngai J. (1996) General anosmia caused by a targeted disruption of the mouse olfactory cyclic nucleotide-gated cation channel. Neuron 17: 681-93 [PMID:8893025]

32. Bucchi A, Baruscotti M and DiFrancesco D. (2002) Current-dependent block of rabbit sino-atrial node $I(f)$ channels by ivabradine. J. Gen. Physiol. 120: 1-13 [PMID:12084770]

33. Bucchi A, Tognati A, Milanesi R, Baruscotti M and DiFrancesco D. (2006) Properties of ivabradine-induced block of HCN1 and HCN4 pacemaker channels. J. Physiol. (Lond.) 572: 335-46 [PMID:16484306]

34. Budde T, Caputi L, Kanyshkova T, Staak R, Abrahamczik C, Munsch T and Pape HC. (2005) Impaired regulation of thalamic pacemaker channels through an imbalance of subunit expression in absence epilepsy. J. Neurosci. 25: 9871-82 [PMID:16251434]

35. Bönigk W, Bradley J, Müller F, Sesti F, Boekhoff I, Ronnett GV, Kaupp UB and Frings S. (1999) The native rat olfactory cyclic nucleotide-gated channel is composed of three distinct subunits. J. Neurosci. 19: 5332-47 [PMID:10377344]

36. Cacheaux LP, Topf N, Tibbs GR, Schaefer UR, Levi R, Harrison NL, Abbott GW and Goldstein PA. (2005) Impairment of hyperpolarization-activated, cyclic nucleotide-gated channel function by the intravenous general anesthetic propofol. J. Pharmacol. Exp. Ther. 315: 517-25 [PMID:16033909]

37. Cao-Ehlker X, Zong X, Hammelmann V, Gruner C, Fenske S, Michalakis S, Wahl-Schott C and Biel M. (2013) Up-regulation of hyperpolarization-activated cyclic nucleotide-gated channel 3 (HCN3) by specific interaction with $\mathrm{K}+$ channel tetramerization domain-containing protein 3 (KCTD3). J. Biol. Chem. 288: 7580-9 [PMID:23382386]

38. Carrisoza-Gaytán R, Rangel C, Salvador C, Saldaña-Meyer R, Escalona C, Satlin LM, Liu W, Zavilowitz B, Trujillo J and Bobadilla NA et al.. (2011) The hyperpolarization-activated cyclic nucleotide-gated HCN2 channel transports ammonium in the distal nephron. Kidney Int. 80: 832-40 [PMID:21796099]

39. Cerbai $E$ and Mugelli A. (2006) I(f) in non-pacemaker cells: role and pharmacological implications. Pharmacol. Res. 53: 416-23 [PMID:16713285]

40. Chan CS, Glajch KE, Gertler TS, Guzman JN, Mercer JN, Lewis AS, Goldberg AB, Tkatch T, Shigemoto R and Fleming SM et al.. (2011) HCN channelopathy in external globus pallidus neurons in models of Parkinson's disease. Nat. Neurosci. 14: 85-92 [PMID:21076425]

41. Chan CS, Shigemoto R, Mercer JN and Surmeier DJ. (2004) HCN2 and HCN1 channels govern the regularity of autonomous pacemaking and synaptic resetting in globus pallidus neurons. J. Neurosci. 24: 9921-32 [PMID:15525777]

42. Chen S, Wang J and Siegelbaum SA. (2001) Properties of hyperpolarization-activated pacemaker current 
defined by coassembly of HCN1 and HCN2 subunits and basal modulation by cyclic nucleotide. J. Gen. Physiol. 117: 491-504 [PMID:11331358]

43. Chen TY, Illing M, Molday LL, Hsu YT, Yau KW and Molday RS. (1994) Subunit 2 (or beta) of retinal rod cGMP-gated cation channel is a component of the $240-\mathrm{kDa}$ channel-associated protein and mediates $\mathrm{Ca}(2+)$-calmodulin modulation. Proc. Natl. Acad. Sci. U.S.A. 91: 11757-61 [PMID:7526403]

44. Chen TY, Peng YW, Dhallan RS, Ahamed B, Reed RR and Yau KW. (1993) A new subunit of the cyclic nucleotide-gated cation channel in retinal rods. Nature 362: 764-7 [PMID:7682292]

45. Chen TY and Yau KW. (1994) Direct modulation by $\mathrm{Ca}(2+)$-calmodulin of cyclic nucleotide-activated channel of rat olfactory receptor neurons. Nature 368: 545-8 [PMID:7511217]

46. Chen X, Shu S, Kennedy DP, Willcox SC and Bayliss DA. (2009) Subunit-specific effects of isoflurane on neuronal Ih in HCN1 knockout mice. J. Neurophysiol. 101: 129-40 [PMID:18971302]

47. Colville CA and Molday RS. (1996) Primary structure and expression of the human beta-subunit and related proteins of the rod photoreceptor cGMP-gated channel. J. Biol. Chem. 271: 32968-74 [PMID:8955140]

48. Dean DM, Nguitragool W, Miri A, McCabe SL and Zimmerman AL. (2002) All-trans-retinal shuts down rod cyclic nucleotide-gated ion channels: a novel role for photoreceptor retinoids in the response to bright light? Proc. Natl. Acad. Sci. U.S.A. 99: 8372-7 [PMID:12034887]

49. Decher N, Bundis F, Vajna R and Steinmeyer K. (2003) KCNE2 modulates current amplitudes and activation kinetics of HCN4: influence of KCNE family members on HCN4 currents. Pflugers Arch. 446 : 633-40 [PMID:12856183]

50. Dekker JP and Yellen G. (2006) Cooperative gating between single HCN pacemaker channels.J. Gen. Physiol. 128: 561-7 [PMID:17043149]

51. Del Lungo M, Melchiorre M, Guandalini L, Sartiani L, Mugelli A, Koncz I, Szel T, Varro A, Romanelli MN and Cerbai E. (2012) Novel blockers of hyperpolarization-activated current with isoform selectivity in recombinant cells and native tissue. Br. J. Pharmacol. 166: 602-16 [PMID:22091830]

52. Della Santina L, Piano I, Cangiano L, Caputo A, Ludwig A, Cervetto L and Gargini C. (2012) Processing of retinal signals in normal and HCN deficient mice. PLoS ONE 7: e29812 [PMID:22279546]

53. Dhallan RS, Macke JP, Eddy RL, Shows TB, Reed RR, Yau KW and Nathans J. (1992) Human rod photoreceptor cGMP-gated channel: amino acid sequence, gene structure, and functional expression. $J$. Neurosci. 12: 3248-56 [PMID:1379636]

54. Dhallan RS, Yau KW, Schrader KA and Reed RR. (1990) Primary structure and functional expression of a cyclic nucleotide-activated channel from olfactory neurons. Nature 347: 184-7 [PMID:1697649]

55. Dibbens LM, Reid CA, Hodgson B, Thomas EA, Phillips AM, Gazina E, Cromer BA, Clarke AL, Baram TZ and Scheffer IE et al.. (2010) Augmented currents of an HCN2 variant in patients with febrile seizure syndromes. Ann. Neurol. 67: 542-6 [PMID:20437590]

56. DiFrancesco D. (1993) Pacemaker mechanisms in cardiac tissue.Annu. Rev. Physiol. 55: 455-72 [PMID:7682045]

57. DiFrancesco JC, Barbuti A, Milanesi R, Coco S, Bucchi A, Bottelli G, Ferrarese C, Franceschetti S, Terragni $B$ and Baruscotti $M$ et al.. (2011) Recessive loss-of-function mutation in the pacemaker HCN2 channel causing increased neuronal excitability in a patient with idiopathic generalized epilepsy. $J$. Neurosci. 31: 17327-37 [PMID:22131395]

58. Ding C, Potter ED, Quu W, Coon SL, Levine MA and Guggino SE. (1997) Cloning and widespread distribution of the rat rod-type cyclic nucleotide-gated cation channel. Am. J. Physiol. 272: C1335-44 [PMID:9142860]

59. Drescher MJ, Barretto RL, Chaturvedi D, Beisel KW, Hatfield JS, Khan KM and Drescher DG. (2002) Expression of subunits for the cAMP-sensitive 'olfactory' cyclic nucleotide-gated ion channel in the cochlea: implications for signal transduction. Brain Res. Mol. Brain Res. 98: 1-14 [PMID:11834291]

60. Dryer SE and Henderson D. (1991) A cyclic GMP-activated channel in dissociated cells of the chick pineal gland. Nature 353: 756-8 [PMID:1719422]

61. Dryja TP, Finn JT, Peng YW, McGee TL, Berson EL and Yau KW. (1995) Mutations in the gene encoding 
the alpha subunit of the rod cGMP-gated channel in autosomal recessive retinitis pigmentosa. Proc. Natl. Acad. Sci. U.S.A. 92: 10177-81 [PMID:7479749]

62. Du L, Wang SJ, Cui J, He WJ and Ruan HZ. (2013) Inhibition of HCN channels within the periaqueductal gray attenuates neuropathic pain in rats. Behav. Neurosci. 127: 325-9 [PMID:23398435]

63. Duhme N, Schweizer PA, Thomas D, Becker R, Schröter J, Barends TR, Schlichting I, Draguhn A, Bruehl C and Katus HA et al.. (2013) Altered HCN4 channel C-linker interaction is associated with familial tachycardia-bradycardia syndrome and atrial fibrillation. Eur. Heart J. 34: 2768-75 [PMID:23178648]

64. El-Kholy W, MacDonald PE, Fox JM, Bhattacharjee A, Xue T, Gao X, Zhang Y, Stieber J, Li RA and Tsushima RG et al.. (2007) Hyperpolarization-activated cyclic nucleotide-gated channels in pancreatic beta-cells. Mol. Endocrinol. 21: 753-64 [PMID:17158221]

65. Emery EC, Young GT, Berrocoso EM, Chen L and McNaughton PA. (2011) HCN2 ion channels play a central role in inflammatory and neuropathic pain. Science 333: 1462-6 [PMID:21903816]

66. Emery EC, Young GT and McNaughton PA. (2012) HCN2 ion channels: an emerging role as the pacemakers of pain. Trends Pharmacol. Sci. 33: 456-63 [PMID:22613784]

67. Fenske S, Mader R, Scharr A, Paparizos C, Cao-Ehlker X, Michalakis S, Shaltiel L, Weidinger M, Stieber J and Feil $S$ et al.. (2011) HCN3 contributes to the ventricular action potential waveform in the murine heart. Circ. Res. 109: 1015-23 [PMID:21903939]

68. Fernández-Velasco M, Goren N, Benito G, Blanco-Rivero J, Boscá L and Delgado C. (2003) Regional distribution of hyperpolarization-activated current (If) and hyperpolarization-activated cyclic nucleotidegated channel mRNA expression in ventricular cells from control and hypertrophied rat hearts. J. Physiol. (Lond.) 553: 395-405 [PMID:14514868]

69. Fesenko EE, Kolesnikov SS and Lyubarsky AL. (1985) Induction by cyclic GMP of cationic conductance in plasma membrane of retinal rod outer segment. Nature 313: 310-3 [PMID:2578616]

70. Finn JT, Krautwurst D, Schroeder JE, Chen TY, Reed RR and Yau KW. (1998) Functional co-assembly among subunits of cyclic-nucleotide-activated, nonselective cation channels, and across species from nematode to human. Biophys. J. 74: 1333-45 [PMID:9512030]

71. Gerstner A, Zong X, Hofmann F and Biel M. (2000) Molecular cloning and functional characterization of a new modulatory cyclic nucleotide-gated channel subunit from mouse retina. J. Neurosci. 20: 1324-32 [PMID:10662822]

72. Giocomo LM, Hussaini SA, Zheng F, Kandel ER, Moser MB and Moser El. (2011) Grid cells use HCN1 channels for spatial scaling. Cell 147: 1159-70 [PMID:22100643]

73. González-del Pozo M, Borrego S, Barragán I, Pieras JI, Santoyo J, Matamala N, Naranjo B, Dopazo J and Antiñolo G. (2011) Mutation screening of multiple genes in Spanish patients with autosomal recessive retinitis pigmentosa by targeted resequencing. PLOS ONE 6: e27894 [PMID:22164218]

74. Gordon SE and Zagotta WN. (1995) A histidine residue associated with the gate of the cyclic nucleotideactivated channels in rod photoreceptors. Neuron 14: 177-83 [PMID:7530019]

75. Goto-Omoto S, Hayashi T, Gekka T, Kubo A, Takeuchi T and Kitahara K. (2006) Compound heterozygous CNGA3 mutations (R436W, L633P) in a Japanese patient with congenital achromatopsia. Vis. Neurosci. 23: 395-402 [PMID:16961972]

76. Graf EM, Heubach JF and Ravens U. (2001) The hyperpolarization-activated current If in ventricular myocytes of non-transgenic and beta2-adrenoceptor overexpressing mice. Naunyn Schmiedebergs Arch. Pharmacol. 364: 131-9 [PMID:11534852]

77. Gravante B, Barbuti A, Milanesi R, Zappi I, Viscomi C and DiFrancesco D. (2004) Interaction of the pacemaker channel HCN1 with filamin A. J. Biol. Chem. 279: 43847-53 [PMID:15292205]

78. Greene D, Kang S, Kosenko A and Hoshi N. (2012) Adrenergic regulation of HCN4 channel requires protein association with $\beta 2$-adrenergic receptor. J. Biol. Chem. 287: 23690-7 [PMID:22613709]

79. Grunwald ME, Yu WP, Yu HH and Yau KW. (1998) Identification of a domain on the beta-subunit of the rod cGMP-gated cation channel that mediates inhibition by calcium-calmodulin. J. Biol. Chem. 273: 914857 [PMID:9535905]

80. Gupta VK, Rajala A, Daly RJ and Rajala RV. (2010) Growth factor receptor-bound protein 14: a new 
modulator of photoreceptor-specific cyclic-nucleotide-gated channel. EMBO Rep. 11: 861-7 [PMID:20890309]

81. Hammelmann V, Zong X, Hofmann F, Michalakis S and Biel M. (2011) The cGMP-dependent protein kinase II Is an inhibitory modulator of the hyperpolarization-activated HCN2 channel. PLoS ONE 6: e17078 [PMID:21347269]

82. Han Y, Noam Y, Lewis AS, Gallagher JJ, Wadman WJ, Baram TZ and Chetkovich DM. (2011) Trafficking and gating of hyperpolarization-activated cyclic nucleotide-gated channels are regulated by interaction with tetratricopeptide repeat-containing Rab8b-interacting protein (TRIP8b) and cyclic AMP at distinct sites. J. Biol. Chem. 286: 20823-34 [PMID:21504900]

83. Harzheim D, Pfeiffer KH, Fabritz L, Kremmer E, Buch T, Waisman A, Kirchhof P, Kaupp UB and Seifert R. (2008) Cardiac pacemaker function of HCN4 channels in mice is confined to embryonic development and requires cyclic AMP. EMBO J. 27: 692-703 [PMID:18219271]

84. He P, Deng J, Zhong X, Zhou Z, Song B and Li L. (2012) Identification of a hyperpolarization-activated cyclic nucleotide-gated channel and its subtypes in the urinary bladder of the rat. Urology 79: 1411.e7-13 [PMID:22446339]

85. Herrmann S, Layh B and Ludwig A. (2011) Novel insights into the distribution of cardiac HCN channels: an expression study in the mouse heart. J. Mol. Cell. Cardiol. 51: 997-1006 [PMID:21945247]

86. Hirano AA, Hack I, Wässle H and Duvoisin RM. (2000) Cloning and immunocytochemical localization of a cyclic nucleotide-gated channel alpha-subunit to all cone photoreceptors in the mouse retina. J. Comp. Neurol. 421: 80-94 [PMID:10813773]

87. Hoesl E, Stieber J, Herrmann S, Feil S, Tybl E, Hofmann F, Feil R and Ludwig A. (2008) Tamoxifeninducible gene deletion in the cardiac conduction system. J. Mol. Cell. Cardiol. 45: 62-9 [PMID:18538341]

88. Hofmann F, Biel M and Kaupp UB. (2005) International Union of Pharmacology. LI. Nomenclature and structure-function relationships of cyclic nucleotide-regulated channels. Pharmacol. Rev. 57: 455-62 [PMID:16382102]

89. Horwitz GC, Lelli A, Géléoc GS and Holt JR. (2010) HCN channels are not required for mechanotransduction in sensory hair cells of the mouse inner ear. PLoS ONE 5: e8627 [PMID:20062532]

90. Horwitz GC, Risner-Janiczek JR, Jones SM and Holt JR. (2011) HCN channels expressed in the inner ear are necessary for normal balance function. J. Neurosci. 31: 16814-25 [PMID:22090507]

91. Hsu YT and Molday RS. (1994) Interaction of calmodulin with the cyclic GMP-gated channel of rod photoreceptor cells. Modulation of activity, affinity purification, and localization. J. Biol. Chem. 269: 2976570 [PMID:7525588]

92. Hurtado R, Bub G and Herzlinger D. (2010) The pelvis-kidney junction contains HCN3, a hyperpolarizationactivated cation channel that triggers ureter peristalsis. Kidney Int. 77: 500-8 [PMID:20032965]

93. Hüttl S, Michalakis S, Seeliger M, Luo DG, Acar N, Geiger H, Hudl K, Mader R, Haverkamp S and Moser $M$ et al.. (2005) Impaired channel targeting and retinal degeneration in mice lacking the cyclic nucleotidegated channel subunit CNGB1. J. Neurosci. 25: 130-8 [PMID:15634774]

94. Jenkins PM, Zhang L, Thomas G and Martens JR. (2009) PACS-1 mediates phosphorylation-dependent ciliary trafficking of the cyclic-nucleotide-gated channel in olfactory sensory neurons. J. Neurosci. 29: 10541-51 [PMID:19710307]

95. Jin ZB, Mandai M, Yokota T, Higuchi K, Ohmori K, Ohtsuki F, Takakura S, Itabashi T, Wada Y and Akimoto $\mathrm{M}$ et al.. (2008) Identifying pathogenic genetic background of simplex or multiplex retinitis pigmentosa patients: a large scale mutation screening study. J. Med. Genet. 45: 465-72 [PMID:18310263]

96. Johnson S, Michaelides M, Aligianis IA, Ainsworth JR, Mollon JD, Maher ER, Moore AT and Hunt DM. (2004) Achromatopsia caused by novel mutations in both CNGA3 and CNGB3. J. Med. Genet. 41: e20 [PMID:14757870]

97. Kanyshkova T, Meuth P, Bista P, Liu Z, Ehling P, Caputi L, Doengi M, Chetkovich DM, Pape HC and Budde T. (2012) Differential regulation of HCN channel isoform expression in thalamic neurons of epileptic and non-epileptic rat strains. Neurobiol. Dis. 45: 450-61 [PMID:21945537]

98. Kaupp UB, Niidome T, Tanabe T, Terada S, Bönigk W, Stühmer W, Cook NJ, Kangawa K, Matsuo H and 
Hirose T. (1989) Primary structure and functional expression from complementary DNA of the rod photoreceptor cyclic GMP-gated channel. Nature 342: 762-6 [PMID:2481236]

99. Kaupp UB and Seifert R. (2001) Molecular diversity of pacemaker ion channels Annu. Rev. Physiol. 63: 235-57 [PMID:11181956]

100. Kaupp UB and Seifert R. (2002) Cyclic nucleotide-gated ion channels.Physiol. Rev. 82: 769-824 [PMID:12087135]

101. Kelliher KR, Ziesmann J, Munger SD, Reed RR and Zufall F. (2003) Importance of the CNGA4 channel gene for odor discrimination and adaptation in behaving mice. Proc. Natl. Acad. Sci. U.S.A. 100: 4299-304 [PMID:12649326]

102. Khan NW, Wissinger B, Kohl S and Sieving PA. (2007) CNGB3 achromatopsia with progressive loss of residual cone function and impaired rod-mediated function. Invest. Ophthalmol. Vis. Sci. 48: 3864-71 [PMID:17652762]

103. Kim CS, Chang PY and Johnston D. (2012) Enhancement of dorsal hippocampal activity by knockdown of HCN1 channels leads to anxiolytic- and antidepressant-like behaviors. Neuron 75: 503-16 [PMID:22884333]

104. Kimura K, Kitano J, Nakajima Y and Nakanishi S. (2004) Hyperpolarization-activated, cyclic nucleotidegated HCN2 cation channel forms a protein assembly with multiple neuronal scaffold proteins in distinct modes of protein-protein interaction. Genes Cells 9: 631-40 [PMID:15265006]

105. Kingston PA, Zufall F and Barnstable CJ. (1999) Widespread expression of olfactory cyclic nucleotidegated channel genes in rat brain: implications for neuronal signalling. Synapse 32: 1-12 [PMID:10188632]

106. Kizhatil K, Baker SA, Arshavsky VY and Bennett V. (2009) Ankyrin-G promotes cyclic nucleotide-gated channel transport to rod photoreceptor sensory cilia. Science 323: 1614-7 [PMID:19299621]

107. Knaus A, Zong X, Beetz N, Jahns R, Lohse MJ, Biel M and Hein L. (2007) Direct inhibition of cardiac hyperpolarization-activated cyclic nucleotide-gated pacemaker channels by clonidine. Circulation 115: 87280 [PMID:17261653]

108. Koch U, Braun M, Kapfer C and Grothe B. (2004) Distribution of HCN1 and HCN2 in rat auditory brainstem nuclei. Eur. J. Neurosci. 20: 79-91 [PMID:15245481]

109. Koeppen K, Reuter P, Kohl S, Baumann B, Ladewig T and Wissinger B. (2008) Functional analysis of human CNGA3 mutations associated with colour blindness suggests impaired surface expression of channel mutants A3(R427C) and A3(R563C). Eur. J. Neurosci. 27: 2391-401 [PMID:18445228]

110. Kohl S, Baumann B, Broghammer M, Jägle H, Sieving P, Kellner U, Spegal R, Anastasi M, Zrenner E and Sharpe LT et al.. (2000) Mutations in the CNGB3 gene encoding the beta-subunit of the cone photoreceptor cGMP-gated channel are responsible for achromatopsia (ACHM3) linked to chromosome 8q21. Hum. Mol. Genet. 9: 2107-16 [PMID:10958649]

111. Kohl S, Marx T, Giddings I, Jägle H, Jacobson SG, Apfelstedt-Sylla E, Zrenner E, Sharpe LT and Wissinger B. (1998) Total colourblindness is caused by mutations in the gene encoding the alpha-subunit of the cone photoreceptor cGMP-gated cation channel. Nat. Genet. 19: 257-9 [PMID:9662398]

112. Kohl S, Varsanyi B, Antunes GA, Baumann B, Hoyng CB, Jägle H, Rosenberg T, Kellner U, Lorenz B and Salati R et al.. (2005) CNGB3 mutations account for $50 \%$ of all cases with autosomal recessive achromatopsia. Eur. J. Hum. Genet. 13: 302-8 [PMID:15657609]

113. Kole MH, Bräuer AU and Stuart GJ. (2007) Inherited cortical HCN1 channel loss amplifies dendritic calcium electrogenesis and burst firing in a rat absence epilepsy model. J. Physiol. (Lond.) 578: 507-25 [PMID:17095562]

114. Kondo H, Qin M, Mizota A, Kondo M, Hayashi H, Hayashi K, Oshima K, Tahira T and Hayashi K. (2004) A homozygosity-based search for mutations in patients with autosomal recessive retinitis pigmentosa, using microsatellite markers. Invest. Ophthalmol. Vis. Sci. 45: 4433-9 [PMID:15557452]

115. Körschen HG, Illing M, Seifert R, Sesti F, Williams A, Gotzes S, Colville C, Müller F, Dosé A and Godde M et al.. (1995) A $240 \mathrm{kDa}$ protein represents the complete beta subunit of the cyclic nucleotide-gated channel from rod photoreceptor. Neuron 15: 627-36 [PMID:7546742]

116. Laish-Farkash A, Glikson M, Brass D, Marek-Yagel D, Pras E, Dascal N, Antzelevitch C, Nof E, Reznik H 
and Eldar M et al.. (2010) A novel mutation in the HCN4 gene causes symptomatic sinus bradycardia in Moroccan Jews. J. Cardiovasc. Electrophysiol. 21: 1365-72 [PMID:20662977]

117. Lee $\mathrm{CH}$ and MacKinnon R. (2017) Structures of the Human HCN1 Hyperpolarization-Activated Channel. Cell 168: 111-120.e11 [PMID:28086084]

118. Lee HM, Park YS, Kim W and Park CS. (2001) Electrophysiological characteristics of rat gustatory cyclic nucleotide--gated channel expressed in Xenopus oocytes. J. Neurophysiol. 85: 2335-49 [PMID:11387380]

119. Lewis AS, Schwartz E, Chan CS, Noam Y, Shin M, Wadman WJ, Surmeier DJ, Baram TZ, Macdonald RL and Chetkovich DM. (2009) Alternatively spliced isoforms of TRIP8b differentially control h channel trafficking and function. J. Neurosci. 29: 6250-65 [PMID:19439603]

120. Lewis AS, Vaidya SP, Blaiss CA, Liu Z, Stoub TR, Brager DH, Chen X, Bender RA, Estep CM and Popov $A B$ et al.. (2011) Deletion of the hyperpolarization-activated cyclic nucleotide-gated channel auxiliary subunit TRIP8b impairs hippocampal Ih localization and function and promotes antidepressant behavior in mice. J. Neurosci. 31: 7424-40 [PMID:21593326]

121. Li M, Zhou X, Wang S, Michailidis I, Gong Y, Su D, Li H, Li X and Yang J. (2017) Structure of a eukaryotic cyclic-nucleotide-gated channel. Nature 542: 60-65 [PMID:28099415]

122. Liman ER and Buck LB. (1994) A second subunit of the olfactory cyclic nucleotide-gated channel confers high sensitivity to CAMP. Neuron 13: 611-21 [PMID:7522482]

123. Lin YC, Huang J, Zhang Q, Hollander JM, Frisbee JC, Martin KH, Nestor C, Goodman R and Yu HG. (2010) Inactivation of L-type calcium channel modulated by HCN2 channel. Am. J. Physiol., Cell Physiol. 298: C1029-37 [PMID:20164379]

124. Liu M, Chen TY, Ahamed B, Li J and Yau KW. (1994) Calcium-calmodulin modulation of the olfactory cyclic nucleotide-gated cation channel. Science 266: 1348-54 [PMID:7526466]

125. Ludwig A, Budde T, Stieber J, Moosmang S, Wahl C, Holthoff K, Langebartels A, Wotjak C, Munsch T, Zong X, Feil S, Feil R, Lancel M, Chien KR, Konnerth A, Pape HC, Biel M and Hofmann F. (2003) Absence epilepsy and sinus dysrhythmia in mice lacking the pacemaker channel HCN2. EMBO J. 22: 21624 [PMID:12514127]

126. Ludwig A, Zong X, Hofmann F and Biel M. (1999) Structure and function of cardiac pacemaker channels. Cell. Physiol. Biochem. 9: 179-86 [PMID:10575196]

127. Ludwig A, Zong X, Jeglitsch M, Hofmann F and Biel M. (1998) A family of hyperpolarization-activated mammalian cation channels. Nature 393: 587-91 [PMID:9634236]

128. Ludwig A, Zong X, Stieber J, Hullin R, Hofmann F and Biel M. (1999) Two pacemaker channels from human heart with profoundly different activation kinetics. EMBO J. 18: 2323-9 [PMID:10228147]

129. Lyashchenko AK, Redd KJ, Yang J and Tibbs GR. (2007) Propofol inhibits HCN1 pacemaker channels by selective association with the closed states of the membrane embedded channel core. J. Physiol. (Lond.) 583: 37-56 [PMID:17569731]

130. Matt L, Michalakis S, Hofmann F, Hammelmann V, Ludwig A, Biel M and Kleppisch T. (2011) HCN2 channels in local inhibitory interneurons constrain LTP in the hippocampal direct perforant path. Cell. Mol. Life Sci. 68: 125-37 [PMID:20623157]

131. Matveev AV, Quiambao AB, Browning Fitzgerald J and Ding XQ. (2008) Native cone photoreceptor cyclic nucleotide-gated channel is a heterotetrameric complex comprising both CNGA3 and CNGB3: a study using the cone-dominant retina of Nrl-/- mice. J. Neurochem. 106: 2042-55 [PMID:18665891]

132. Meuth SG, Kanyshkova T, Meuth P, Landgraf P, Munsch T, Ludwig A, Hofmann F, Pape HC and Budde T. (2006) Membrane resting potential of thalamocortical relay neurons is shaped by the interaction among TASK3 and HCN2 channels. J. Neurophysiol. 96: 1517-29 [PMID:16760342]

133. Meyer MR, Angele A, Kremmer E, Kaupp UB and Muller F. (2000) A cGMP-signaling pathway in a subset of olfactory sensory neurons. Proc. Natl. Acad. Sci. U.S.A. 97: 10595-600 [PMID:10984544]

134. Michaelides M, Aligianis IA, Ainsworth JR, Good P, Mollon JD, Maher ER, Moore AT and Hunt DM. (2004) Progressive cone dystrophy associated with mutation in CNGB3. Invest. Ophthalmol. Vis. Sci. 45: 1975-82 [PMID:15161866]

135. Michalakis S, Geiger H, Haverkamp S, Hofmann F, Gerstner A and Biel M. (2005) Impaired opsin targeting 
and cone photoreceptor migration in the retina of mice lacking the cyclic nucleotide-gated channel CNGA3. Invest. Ophthalmol. Vis. Sci. 46: 1516-24 [PMID:15790924]

136. Michalakis S, Reisert J, Geiger H, Wetzel C, Zong X, Bradley J, Spehr M, Hüttl S, Gerstner A and Pfeifer A et al.. (2006) Loss of CNGB1 protein leads to olfactory dysfunction and subciliary cyclic nucleotide-gated channel trapping. J. Biol. Chem. 281: 35156-66 [PMID:16980309]

137. Michalakis S, Zong X, Becirovic E, Hammelmann V, Wein T, Wanner KT and Biel M. (2011) The glutamic acid-rich protein is a gating inhibitor of cyclic nucleotide-gated channels. J. Neurosci. 31: 133-41 [PMID:21209198]

138. Michels G, Er F, Khan I, Südkamp M, Herzig S and Hoppe UC. (2005) Single-channel properties support a potential contribution of hyperpolarization-activated cyclic nucleotide-gated channels and If to cardiac arrhythmias. Circulation 111: 399-404 [PMID:15687126]

139. Michels G, Er F, Khan IF, Endres-Becker J, Brandt MC, Gassanov N, Johns DC and Hoppe UC. (2008) K+ channel regulator KCR1 suppresses heart rhythm by modulating the pacemaker current If. PLOS ONE 3: e1511 [PMID:18231597]

140. Milanesi R, Baruscotti M, Gnecchi-Ruscone T and DiFrancesco D. (2006) Familial sinus bradycardia associated with a mutation in the cardiac pacemaker channel. N. Engl. J. Med. 354: 151-7 [PMID:16407510]

141. Misaka T, Ishimaru Y, Iwabuchi K, Kusakabe Y, Arai S, Emori Y and Abe K. (1999) A gustatory cyclic nucleotide-gated channels CNGgust, is expressed in the retina. Neuroreport 10: 743-6 [PMID:10208541]

142. Misaka T, Kusakabe Y, Emori Y, Gonoi T, Arai S and Abe K. (1997) Taste buds have a cyclic nucleotideactivated channel, CNGgust. J. Biol. Chem. 272: 22623-9 [PMID:9278419]

143. Mistrík P, Mader R, Michalakis S, Weidinger M, Pfeifer A and Biel M. (2005) The murine HCN3 gene encodes a hyperpolarization-activated cation channel with slow kinetics and unique response to cyclic nucleotides. J. Biol. Chem. 280: 27056-61 [PMID:15923185]

144. Mobley AS, Miller AM, Araneda RC, Maurer LR, Müller F and Greer CA. (2010) Hyperpolarizationactivated cyclic nucleotide-gated channels in olfactory sensory neurons regulate axon extension and glomerular formation. J. Neurosci. 30: 16498-508 [PMID:21147989]

145. Molday RS and Molday LL. (1998) Molecular properties of the cGMP-gated channel of rod photoreceptors. Vision Res. 38: 1315-23 [PMID:9666999]

146. Monteggia LM, Eisch AJ, Tang MD, Kaczmarek LK and Nestler EJ. (2000) Cloning and localization of the hyperpolarization-activated cyclic nucleotide-gated channel family in rat brain. Brain Res. Mol. Brain Res.

81: 129-39 [PMID:11000485]

147. Moosmang S, Biel M, Hofmann F and Ludwig A. (1999) Differential distribution of four hyperpolarizationactivated cation channels in mouse brain. Biol. Chem. 380: 975-80 [PMID:10494850]

148. Moosmang S, Stieber J, Zong X, Biel M, Hofmann F and Ludwig A. (2001) Cellular expression and functional characterization of four hyperpolarization-activated pacemaker channels in cardiac and neuronal tissues. Eur. J. Biochem. 268: 1646-52 [PMID:11248683]

149. Much B, Wahl-Schott C, Zong X, Schneider A, Baumann L, Moosmang S, Ludwig A and Biel M. (2003) Role of subunit heteromerization and $\mathrm{N}$-linked glycosylation in the formation of functional hyperpolarization-activated cyclic nucleotide-gated channels. J. Biol. Chem. 278: 43781-6 [PMID:12928435]

150. Munger SD, Lane AP, Zhong H, Leinders-Zufall T, Yau KW, Zufall F and Reed RR. (2001) Central role of the CNGA4 channel subunit in Ca2+-calmodulin-dependent odor adaptation. Science 294: 2172-5 [PMID:11739959]

151. Müller F, Scholten A, Ivanova E, Haverkamp S, Kremmer E and Kaupp UB. (2003) HCN channels are expressed differentially in retinal bipolar cells and concentrated at synaptic terminals. Eur. J. Neurosci.17: 2084-96 [PMID:12786975]

152. Nache V, Zimmer T, Wongsamitkul N, Schmauder R, Kusch J, Reinhardt L, Bönigk W, Seifert R, Biskup C and Schwede $\mathrm{F}$ et al.. (2012) Differential regulation by cyclic nucleotides of the CNGA4 and CNGB1b subunits in olfactory cyclic nucleotide-gated channels. Sci Signal 5: ra48 [PMID:22786723] 
153. Nakamura T and Gold GH. (1987) A cyclic nucleotide-gated conductance in olfactory receptor cilia.Nature 325: 442-4 [PMID:3027574]

154. Nishiguchi KM, Sandberg MA, Gorji N, Berson EL and Dryja TP. (2005) Cone cGMP-gated channel mutations and clinical findings in patients with achromatopsia, macular degeneration, and other hereditary cone diseases. Hum. Mutat. 25: 248-58 [PMID:15712225]

155. Nof E, Luria D, Brass D, Marek D, Lahat H, Reznik-Wolf H, Pras E, Dascal N, Eldar M and Glikson M. (2007) Point mutation in the HCN4 cardiac ion channel pore affecting synthesis, trafficking, and functional expression is associated with familial asymptomatic sinus bradycardia. Circulation 116: 463-70 [PMID:17646576]

156. Nolan MF, Dudman JT, Dodson PD and Santoro B. (2007) HCN1 channels control resting and active integrative properties of stellate cells from layer II of the entorhinal cortex. J. Neurosci. 27: 12440-51 [PMID:18003822]

157. Nolan MF, Malleret G, Dudman JT, Buhl DL, Santoro B, Gibbs E, Vronskaya S, Buzsáki G, Siegelbaum SA and Kandel ER et al.. (2004) A behavioral role for dendritic integration: HCN1 channels constrain spatial memory and plasticity at inputs to distal dendrites of CA1 pyramidal neurons. Cell 119: 719-32 [PMID:15550252]

158. Nolan MF, Malleret G, Lee KH, Gibbs E, Dudman JT, Santoro B, Yin D, Thompson RF, Siegelbaum SA and Kandel ER et al.. (2003) The hyperpolarization-activated HCN1 channel is important for motor learning and neuronal integration by cerebellar Purkinje cells. Cell 115: 551-64 [PMID:14651847]

159. Notomi T and Shigemoto R. (2004) Immunohistochemical localization of Ih channel subunits, HCN1-4, in the rat brain. J. Comp. Neurol. 471: 241-76 [PMID:14991560]

160. Oh YJ, Na J, Jeong JH, Park DK, Park KH, Ko JS and Kim DS. (2012) Alterations in hyperpolarizationactivated cyclic nucleotidegated cation channel $(\mathrm{HCN})$ expression in the hippocampus following pilocarpine-induced status epilepticus. BMB Rep 45: 635-40 [PMID:23187002]

161. Okada A, Ueyama H, Toyoda F, Oda S, Ding WG, Tanabe S, Yamade S, Matsuura H, Ohkubo I and Kani K. (2004) Functional role of hCngb3 in regulation of human cone cng channel: effect of rod monochromacy-associated mutations in hCNGB3 on channel function. Invest. Ophthalmol. Vis. Sci. 45: 2324-32 [PMID:15223812]

162. Paloma E, Martínez-Mir A, García-Sandoval B, Ayuso C, Vilageliu L, Gonzàlez-Duarte R and Balcells S. (2002) Novel homozygous mutation in the alpha subunit of the rod cGMP gated channel (CNGA1) in two Spanish sibs affected with autosomal recessive retinitis pigmentosa. J. Med. Genet. 39: E66 [PMID:12362048]

163. Paoletti P, Young EC and Siegelbaum SA. (1999) C-Linker of cyclic nucleotide-gated channels controls coupling of ligand binding to channel gating. J. Gen. Physiol. 113: 17-34 [PMID:9874685]

164. Pape HC. (1996) Queer current and pacemaker: the hyperpolarization-activated cation current in neurons. Annu. Rev. Physiol. 58: 299-327 [PMID:8815797]

165. Papp I, Holló K and Antal M. (2010) Plasticity of hyperpolarization-activated and cyclic nucleotid-gated cation channel subunit 2 expression in the spinal dorsal horn in inflammatory pain. Eur. J. Neurosci. 32: 1193-201 [PMID:20726890]

166. Peng C, Rich ED, Thor CA and Varnum MD. (2003) Functionally important calmodulin-binding sites in both $\mathrm{NH} 2$ - and $\mathrm{COOH}$-terminal regions of the cone photoreceptor cyclic nucleotide-gated channel CNGB3 subunit. J. Biol. Chem. 278: 24617-23 [PMID:12730238]

167. Peng C, Rich ED and Varnum MD. (2003) Achromatopsia-associated mutation in the human cone photoreceptor cyclic nucleotide-gated channel CNGB3 subunit alters the ligand sensitivity and pore properties of heteromeric channels. J. Biol. Chem. 278: 34533-40 [PMID:12815043]

168. Peng C, Rich ED and Varnum MD. (2004) Subunit configuration of heteromeric cone cyclic nucleotidegated channels. Neuron 42: 401-10 [PMID:15134637]

169. Pian P, Bucchi A, Robinson RB and Siegelbaum SA. (2006) Regulation of gating and rundown of HCN hyperpolarization-activated channels by exogenous and endogenous PIP2. J. Gen. Physiol. 128: 593-604 [PMID:17074978] 
170. Pifferi S, Boccaccio A and Menini A. (2006) Cyclic nucleotide-gated ion channels in sensory transduction. FEBS Lett. 580: 2853-9 [PMID:16631748]

171. Piskorowski R, Santoro B and Siegelbaum SA. (2011) TRIP8b splice forms act in concert to regulate the localization and expression of HCN1 channels in CA1 pyramidal neurons. Neuron 70: 495-509 [PMID:21555075]

172. Pittler SJ, Lee AK, Altherr MR, Howard TA, Seldin MF, Hurwitz RL, Wasmuth JJ and Baehr W. (1992) Primary structure and chromosomal localization of human and mouse rod photoreceptor cGMP-gated cation channel. J. Biol. Chem. 267: 6257-62 [PMID:1372902]

173. Poetsch A, Molday LL and Molday RS. (2001) The cGMP-gated channel and related glutamic acid-rich proteins interact with peripherin-2 at the rim region of rod photoreceptor disc membranes. J. Biol. Chem. 276: 48009-16 [PMID:11641407]

174. Qu J, Altomare C, Bucchi A, DiFrancesco D and Robinson RB. (2002) Functional comparison of HCN isoforms expressed in ventricular and HEK 293 cells. Pflugers Arch. 444: 597-601 [PMID:12194012]

175. Qu J, Kryukova Y, Potapova IA, Doronin SV, Larsen M, Krishnamurthy G, Cohen IS and Robinson RB. (2004) MiRP1 modulates HCN2 channel expression and gating in cardiac myocytes. J. Biol. Chem. 279: 43497-502 [PMID:15292247]

176. Ramakrishnan NA, Drescher MJ, Barretto RL, Beisel KW, Hatfield JS and Drescher DG. (2009) Calciumdependent binding of HCN1 channel protein to hair cell stereociliary tip link protein protocadherin 15 CD3. J. Biol. Chem. 284: 3227-38 [PMID:19008224]

177. Ramakrishnan NA, Drescher MJ, Khan KM, Hatfield JS and Drescher DG. (2012) HCN1 and HCN2 proteins are expressed in cochlear hair cells: $\mathrm{HCN} 1$ can form a ternary complex with protocadherin $15 \mathrm{CD} 3$ and F-actin-binding filamin A or can interact with HCN2. J. Biol. Chem. 287: 37628-46 [PMID:22948144]

178. Rebrik TI, Botchkina I, Arshavsky VY, Craft CM and Korenbrot JI. (2012) CNG-modulin: a novel Cadependent modulator of ligand sensitivity in cone photoreceptor cGMP-gated ion channels. J. Neurosci. 32: 3142-53 [PMID:22378887]

179. Reuter P, Koeppen K, Ladewig T, Kohl S, Baumann B, Wissinger B and Achromatopsia Clinical Study Group. (2008) Mutations in CNGA3 impair trafficking or function of cone cyclic nucleotide-gated channels, resulting in achromatopsia. Hum. Mutat. 29: 1228-36 [PMID:18521937]

180. Robinson RB and Siegelbaum SA. (2003) Hyperpolarization-activated cation currents: from molecules to physiological function. Annu. Rev. Physiol. 65: 453-80 [PMID:12471170]

181. Rosenbaum T, Gordon-Shaag A, Islas LD, Cooper J, Munari M and Gordon SE. (2004) State-dependent block of CNG channels by dequalinium. J. Gen. Physiol. 123: 295-304 [PMID:14981138]

182. Rosenbaum T, Islas LD, Carlson AE and Gordon SE. (2003) Dequalinium: a novel, high-affinity blocker of CNGA1 channels. J. Gen. Physiol. 121: 37-47 [PMID:12508052]

183. Ruiz ML, London B and Nadal-Ginard B. (1996) Cloning and characterization of an olfactory cyclic nucleotide-gated channel expressed in mouse heart. J. Mol. Cell. Cardiol. 28: 1453-61 [PMID:8841933]

184. Santoro B, Grant SG, Bartsch D and Kandel ER. (1997) Interactive cloning with the SH3 domain of N-src identifies a new brain specific ion channel protein, with homology to eag and cyclic nucleotide-gated channels. Proc. Natl. Acad. Sci. U.S.A. 94: 14815-20 [PMID:9405696]

185. Santoro B, Hu L, Liu H, Saponaro A, Pian P, Piskorowski RA, Moroni A and Siegelbaum SA. (2011) TRIP8b regulates HCN1 channel trafficking and gating through two distinct C-terminal interaction sites. J. Neurosci. 31: 4074-86 [PMID:21411649]

186. Santoro B, Lee JY, Englot DJ, Gildersleeve S, Piskorowski RA, Siegelbaum SA, Winawer MR and Blumenfeld H. (2010) Increased seizure severity and seizure-related death in mice lacking HCN1 channels. Epilepsia 51: 1624-7 [PMID:20384728]

187. Santoro B, Liu DT, Yao H, Bartsch D, Kandel ER, Siegelbaum SA and Tibbs GR. (1998) Identification of a gene encoding a hyperpolarization-activated pacemaker channel of brain. Cell 93: 717-29 [PMID:9630217]

188. Santoro B, Piskorowski RA, Pian P, Hu L, Liu H and Siegelbaum SA. (2009) TRIP8b splice variants form a family of auxiliary subunits that regulate gating and trafficking of $\mathrm{HCN}$ channels in the brain. Neuron 62 : 802-13 [PMID:19555649] 
189. Santoro B, Wainger BJ and Siegelbaum SA. (2004) Regulation of HCN channel surface expression by a novel C-terminal protein-protein interaction. J. Neurosci. 24: 10750-62 [PMID:15564593]

190. Santos-Vera B, Vázquez-Torres R, Marrero HG, Acevedo JM, Arencibia-Albite F, Vélez-Hernández ME, Miranda JD and Jiménez-Rivera CA. (2013) Cocaine sensitization increases I h current channel subunit 2 $\left(\mathrm{HCN}_{2}\right)$ protein expression in structures of the mesocorticolimbic system. J. Mol. Neurosci. 50: 234-45 [PMID:23203153]

191. Sautter A, Biel M and Hofmann F. (1997) Molecular cloning of cyclic nucleotide-gated cation channel subunits from rat pineal gland. Brain Res. Mol. Brain Res. 48: 171-5 [PMID:9379842]

192. Sautter A, Zong X, Hofmann F and Biel M. (1998) An isoform of the rod photoreceptor cyclic nucleotidegated channel beta subunit expressed in olfactory neurons. Proc. Natl. Acad. Sci. U.S.A. 95: 4696-701 [PMID:9539801]

193. Schorderet DF, louranova A, Favez T, Tiab L and Escher P. (2013) IROme, a new high-throughput molecular tool for the diagnosis of inherited retinal dystrophies. Biomed Res Int 2013: 198089 [PMID:23484092]

194. Schulze-Bahr E, Neu A, Friederich P, Kaupp UB, Breithardt G, Pongs O and Isbrandt D. (2003) Pacemaker channel dysfunction in a patient with sinus node disease. J. Clin. Invest. 111: 1537-45 [PMID:12750403]

195. Seeliger MW, Brombas A, Weiler R, Humphries P, Knop G, Tanimoto N and Müller F. (2011) Modulation of rod photoreceptor output by HCN1 channels is essential for regular mesopic cone vision. Nat Commun 2: 532 [PMID:22068599]

196. Seifert R, Scholten A, Gauss R, Mincheva A, Lichter P and Kaupp UB. (1999) Molecular characterization of a slowly gating human hyperpolarization-activated channel predominantly expressed in thalamus, heart, and testis. Proc. Natl. Acad. Sci. U.S.A. 96: 9391-6 [PMID:10430953]

197. Selvakumar D, Drescher MJ, Dowdall JR, Khan KM, Hatfield JS, Ramakrishnan NA and Drescher DG. (2012) CNGA3 is expressed in inner ear hair cells and binds to an intracellular C-terminus domain of EMILIN1. Biochem. J. 443: 463-76 [PMID:22248097]

198. Selvakumar D, Drescher MJ and Drescher DG. (2013) Cyclic nucleotide-gated channel $\alpha-3$ (CNGA3) interacts with stereocilia tip-link cadherin $23+$ exon 68 or alternatively with myosin VIIa, two proteins required for hair cell mechanotransduction. J. Biol. Chem. 288: 7215-29 [PMID:23329832]

199. Shi W, Wymore R, Yu H, Wu J, Wymore RT, Pan Z, Robinson RB, Dixon JE, McKinnon D and Cohen IS. (1999) Distribution and prevalence of hyperpolarization-activated cation channel (HCN) mRNA expression in cardiac tissues. Circ. Res. 85: e1-6 [PMID:10400919]

200. Simpson DA, Clark GR, Alexander S, Silvestri G and Willoughby CE. (2011) Molecular diagnosis for heterogeneous genetic diseases with targeted high-throughput DNA sequencing applied to retinitis pigmentosa. J. Med. Genet. 48: 145-51 [PMID:21147909]

201. Song J, Smaoui N, Ayyagari R, Stiles D, Benhamed S, MacDonald IM, Daiger SP, Tumminia SJ, Hejtmancik F and Wang X. (2011) High-throughput retina-array for screening 93 genes involved in inherited retinal dystrophy. Invest. Ophthalmol. Vis. Sci. 52: 9053-60 [PMID:22025579]

202. Stevens DR, Seifert R, Bufe B, Müller F, Kremmer E, Gauss R, Meyerhof W, Kaupp UB and Lindemann B. (2001) Hyperpolarization-activated channels HCN1 and HCN4 mediate responses to sour stimuli. Nature 413: 631-5 [PMID:11675786]

203. Stieber J, Herrmann S, Feil S, Löster J, Feil R, Biel M, Hofmann F and Ludwig A. (2003) The hyperpolarization-activated channel HCN4 is required for the generation of pacemaker action potentials in the embryonic heart. Proc. Natl. Acad. Sci. U.S.A. 100: 15235-40 [PMID:14657344]

204. Stieber J, Stöckl G, Herrmann S, Hassfurth B and Hofmann F. (2005) Functional expression of the human HCN3 channel. J. Biol. Chem. 280: 34635-43 [PMID:16043489]

205. Stieber J, Wieland K, Stöckl G, Ludwig A and Hofmann F. (2006) Bradycardic and proarrhythmic properties of sinus node inhibitors. Mol. Pharmacol. 69: 1328-37 [PMID:16387796]

206. Sundin OH, Yang JM, Li Y, Zhu D, Hurd JN, Mitchell TN, Silva ED and Maumenee IH. (2000) Genetic basis of total colourblindness among the Pingelapese islanders. Nat. Genet. 25: 289-93 [PMID:10888875] 
207. Surges R, Kukley M, Brewster A, Rüschenschmidt C, Schramm J, Baram TZ, Beck H and Dietrich D. (2012) Hyperpolarization-activated cation current Ih of dentate gyrus granule cells is upregulated in human and rat temporal lobe epilepsy. Biochem. Biophys. Res. Commun. 420: 156-60 [PMID:22405820]

208. Tang B, Sander T, Craven KB, Hempelmann A and Escayg A. (2008) Mutation analysis of the hyperpolarization-activated cyclic nucleotide-gated channels HCN1 and HCN2 in idiopathic generalized epilepsy. Neurobiol. Dis. 29: 59-70 [PMID:17931874]

209. Thiadens AA, Roosing S, Collin RW, van Moll-Ramirez N, van Lith-Verhoeven JJ, van Schooneveld MJ, den Hollander Al, van den Born LI, Hoyng CB and Cremers FP et al.. (2010) Comprehensive analysis of the achromatopsia genes CNGA3 and CNGB3 in progressive cone dystrophy. Ophthalmology 117: 82530.e1 [PMID:20079539]

210. Thiadens AA, Slingerland NW, Roosing S, van Schooneveld MJ, van Lith-Verhoeven JJ, van Moll-Ramirez N, van den Born LI, Hoyng CB, Cremers FP and Klaver CC. (2009) Genetic etiology and clinical consequences of complete and incomplete achromatopsia. Ophthalmology 116: 1984-9.e1 [PMID:19592100]

211. Trudeau MC and Zagotta WN. (2002) An intersubunit interaction regulates trafficking of rod cyclic nucleotide-gated channels and is disrupted in an inherited form of blindness. Neuron 34: 197-207 [PMID:11970862]

212. Tu E, Waterhouse L, Duflou J, Bagnall RD and Semsarian C. (2011) Genetic analysis of hyperpolarization-activated cyclic nucleotide-gated cation channels in sudden unexpected death in epilepsy cases. Brain Pathol. 21: 692-8 [PMID:21615589]

213. Ueda K, Nakamura K, Hayashi T, Inagaki N, Takahashi M, Arimura T, Morita H, Higashiuesato Y, Hirano Y and Yasunami $\mathrm{M}$ et al.. (2004) Functional characterization of a trafficking-defective HCN4 mutation, D553N, associated with cardiac arrhythmia. J. Biol. Chem. 279: 27194-8 [PMID:15123648]

214. Ulens $\mathrm{C}$ and Tytgat J. (2001) Functional heteromerization of HCN1 and HCN2 pacemaker channels.J. Biol. Chem. 276: 6069-72 [PMID:11133998]

215. Ungerer N, Mücke N, Broecker J, Keller S, Frings S and Möhrlen F. (2011) Distinct binding properties distinguish LQ-type calmodulin-binding domains in cyclic nucleotide-gated channels. Biochemistry 50: 3221-8 [PMID:21413724]

216. Varsányi B, Wissinger B, Kohl S, Koeppen K and Farkas A. (2005) Clinical and genetic features of Hungarian achromatopsia patients. Mol. Vis. 11: 996-1001 [PMID:16319819]

217. Vemana S, Pandey S and Larsson HP. (2008) Intracellular Mg2+ is a voltage-dependent pore blocker of HCN channels. Am. J. Physiol., Cell Physiol. 295: C557-65 [PMID:18579800]

218. Wainger BJ, DeGennaro M, Santoro B, Siegelbaum SA and Tibbs GR. (2001) Molecular mechanism of cAMP modulation of HCN pacemaker channels. Nature 411: 805-10 [PMID:11459060]

219. Wan Y. (2008) Involvement of hyperpolarization-activated, cyclic nucleotide-gated cation channels in dorsal root ganglion in neuropathic pain. Sheng Li Xue Bao60: 579-80 [PMID:18958363]

220. Wang J, Chen S and Siegelbaum SA. (2001) Regulation of hyperpolarization-activated HCN channel gating and cAMP modulation due to interactions of $\mathrm{COOH}$ terminus and core transmembrane regions. J. Gen. Physiol. 118: 237-50 [PMID:11524455]

221. Wei JY, Cohen ED and Barnstable CJ. (1997) Direct blockade of both cloned rat rod photoreceptor cyclic nucleotide-gated non-selective cation (CNG) channel alpha-subunit and native CNG channels from Xenopus rod outer segments by $\mathrm{H}-8$, a non-specific cyclic nucleotide-dependent protein kinase inhibitor. Neurosci. Lett. 233: 37-40 [PMID:9324234]

222. Weitz D, Ficek N, Kremmer E, Bauer PJ and Kaupp UB. (2002) Subunit stoichiometry of the CNG channel of rod photoreceptors. Neuron 36: 881-9 [PMID:12467591]

223. Weyand I, Godde M, Frings S, Weiner J, Müller F, Altenhofen W, Hatt H and Kaupp UB. (1994) Cloning and functional expression of a cyclic-nucleotide-gated channel from mammalian sperm. Nature 368: 85963 [PMID:7512693]

224. Wiesner B, Weiner J, Middendorff R, Hagen V, Kaupp UB and Weyand I. (1998) Cyclic nucleotide-gated channels on the flagellum control Ca2+ entry into sperm. J. Cell Biol. 142: 473-84 [PMID:9679145] 
225. Wilkars W, Liu Z, Lewis AS, Stoub TR, Ramos EM, Brandt N, Nicholson DA, Chetkovich DM and Bender RA. (2012) Regulation of axonal HCN1 trafficking in perforant path involves expression of specific TRIP8b isoforms. PLoS ONE 7: e32181 [PMID:22363812]

226. Wissinger B, Gamer D, Jägle H, Giorda R, Marx T, Mayer S, Tippmann S, Broghammer M, Jurklies B, Rosenberg T, Jacobson SG, Sener EC, Tatlipinar S, Hoyng CB, Castellan C, Bitoun P, Andreasson S, Rudolph G, Kellner U, Lorenz B, Wolff G, Verellen-Dumoulin C, Schwartz M, Cremers FP, Apfelstedt-Sylla E, Zrenner E, Salati R, Sharpe LT and Kohl S. (2001) CNGA3 mutations in hereditary cone photoreceptor disorders. Am. J. Hum. Genet. 69: 722-37 [PMID:11536077]

227. Wissinger B, Müller F, Weyand I, Schuffenhauer S, Thanos S, Kaupp UB and Zrenner E. (1997) Cloning, chromosomal localization and functional expression of the gene encoding the alpha-subunit of the cGMPgated channel in human cone photoreceptors. Eur. J. Neurosci. 9: 2512-21 [PMID:9517456]

228. Wiszniewski W, Lewis RA and Lupski JR. (2007) Achromatopsia: the CNGB3 p.T383fsX mutation results from a founder effect and is responsible for the visual phenotype in the original report of uniparental disomy 14. Hum. Genet. 121: 433-9 [PMID:17265047]

229. Xia S, Wang Y, Zhang Y, Deng SB, Du JL, Wang XC and She Q. (2010) Dynamic changes in HCN2, HCN4, KCNE1, and KCNE2 expression in ventricular cells from acute myocardial infarction rat hearts. Biochem. Biophys. Res. Commun. 395: 330-5 [PMID:20381460]

230. Xiao J, Nguyen TV, Ngui K, Strijbos PJ, Selmer IS, Neylon CB and Furness JB. (2004) Molecular and functional analysis of hyperpolarisation-activated nucleotide-gated $(\mathrm{HCN})$ channels in the enteric nervous system. Neuroscience 129: 603-14 [PMID:15541882]

231. Xu X, Marni F, Wu S, Su Z, Musayev F, Shrestha S, Xie C, Gao W, Liu Q and Zhou L. (2012) Local and global interpretations of a disease-causing mutation near the ligand entry path in hyperpolarizationactivated cAMP-gated channel. Structure 20: 2116-23 [PMID:23103389]

232. Yang S, Xiong CJ, Sun HM, Li XS, Zhang GQ, Wu B and Zhou DS. (2012) The distribution of HCN2positive cells in the gastrointestinal tract of mice. J. Anat. 221: 303-10 [PMID:22803609]

233. Yasui K, Liu W, Opthof T, Kada K, Lee JK, Kamiya K and Kodama I. (2001) I(f) current and spontaneous activity in mouse embryonic ventricular myocytes. Circ. Res. 88: 536-42 [PMID:11249878]

234. Ying SW, Jia F, Abbas SY, Hofmann F, Ludwig A and Goldstein PA. (2007) Dendritic HCN2 channels constrain glutamate-driven excitability in reticular thalamic neurons. J. Neurosci. 27: 8719-32 [PMID:17687049]

235. Ying SW, Kanda VA, Hu Z, Purtell K, King EC, Abbott GW and Goldstein PA. (2012) Targeted deletion of Kcne2 impairs HCN channel function in mouse thalamocortical circuits. PLoS ONE 7: e42756 [PMID:22880098]

236. Yu WP, Grunwald ME and Yau KW. (1996) Molecular cloning, functional expression and chromosomal localization of a human homolog of the cyclic nucleotide-gated ion channel of retinal cone photoreceptors. FEBS Lett. 393: 211-5 [PMID:8814292]

237. Yu X, Chen XW, Zhou P, Yao L, Liu T, Zhang B, Li Y, Zheng H, Zheng LH and Zhang Cæt al.. (2007) Calcium influx through If channels in rat ventricular myocytes. Am. J. Physiol., Cell Physiol. 292: C1147-55 [PMID:17065201]

238. Yu X, Duan KL, Shang CF, Yu HG and Zhou Z. (2004) Calcium influx through hyperpolarization-activated cation channels (l(h) channels) contributes to activity-evoked neuronal secretion. Proc. Natl. Acad. Sci. U.S.A. 101: 1051-6 [PMID:14724293]

239. Zhang Q, Zulfiqar F, Riazuddin SA, Xiao X, Ahmad Z, Riazuddin S and Hejtmancik JF. (2004) Autosomal recessive retinitis pigmentosa in a Pakistani family mapped to CNGA1 with identification of a novel mutation. Mol. Vis. 10: 884-9 [PMID:15570217]

240. Zhang Y, Liu Y, Qu J, Hardy A, Zhang N, Diao J, Strijbos PJ, Tsushima R, Robinson RB and Gaisano HY et al.. (2009) Functional characterization of hyperpolarization-activated cyclic nucleotide-gated channels in rat pancreatic beta cells. J. Endocrinol. 203: 45-53 [PMID:19654142]

241. Zheng J, Trudeau MC and Zagotta WN. (2002) Rod cyclic nucleotide-gated channels have a stoichiometry of three CNGA1 subunits and one CNGB1 subunit. Neuron 36: 891-6 [PMID:12467592] 
242. Zheng $\mathrm{J}$ and Zagotta WN. (2004) Stoichiometry and assembly of olfactory cyclic nucleotide-gated channels. Neuron 42: 411-21 [PMID:15134638]

243. Zhong H, Molday LL, Molday RS and Yau KW. (2002) The heteromeric cyclic nucleotide-gated channel adopts a 3A:1B stoichiometry. Nature 420: 193-8 [PMID:12432397]

244. Zhou C, Douglas JE, Kumar NN, Shu S, Bayliss DA and Chen X. (2013) Forebrain HCN1 channels contribute to hypnotic actions of ketamine. Anesthesiology 118: 785-95 [PMID:23377220]

245. Zolles G, Wenzel D, Bildl W, Schulte U, Hofmann A, Müller CS, Thumfart JO, Vlachos A, Deller T and Pfeifer A et al.. (2009) Association with the auxiliary subunit PEX5R/Trip8b controls responsiveness of HCN channels to cAMP and adrenergic stimulation. Neuron 62: 814-25 [PMID:19555650]

246. Zong X, Eckert C, Yuan H, Wahl-Schott C, Abicht H, Fang L, Li R, Mistrik P, Gerstner A and Much tal.. (2005) A novel mechanism of modulation of hyperpolarization-activated cyclic nucleotide-gated channels by Src kinase. J. Biol. Chem. 280: 34224-32 [PMID:16079136]

247. Zong X, Krause S, Chen CC, Krüger J, Gruner C, Cao-Ehlker X, Fenske S, Wahl-Schott C and Biel M. (2012) Regulation of hyperpolarization-activated cyclic nucleotide-gated (HCN) channel activity by cCMP. J. Biol. Chem. 287: 26506-12 [PMID:22715094] 